\title{
Salinity Effect on Seed Germination and Growth of Two Warm-season Native Grass Species
}

\author{
Qi Zhang ${ }^{1,4}$, Kevin Rue ${ }^{2}$, and Sheng Wang ${ }^{3}$ \\ Department of Plant Sciences, North Dakota State University, Department \\ \#7670, P.O. Box 6050, Fargo, ND 58108
}

Additional index words. $\mathrm{NaCl}$, buffalograss, blue grama

\begin{abstract}
Salinity tolerance of five buffalograss [Buchloe dactyloides (Nutt.) Englem.] cultivars (Texoka, Cody, Bison, Sharp's Improved II, and Bowie) and three blue grama [Bouteloua gracilis (Willd. ex Kunth) Lag. ex Griffiths] ecotypes ('Lovington', 'Hachita', and 'Bad River') was determined during in vitro seed germination and vegetative growth in a hydroponic system. Seeds were germinated on $0.6 \%$ agar medium supplemented with $\mathrm{NaCl}$ at $0,5,10,15$, and $20 \mathrm{~g} \cdot \mathrm{L}^{-1}$. Salinity reduced the final germination rate (FGR) and daily germination rate (DGR). Similarly, shoot dry weight (SDW), longest root length (LRL), and percentage of green tissue (PGT) of mature grasses declined with increasing salinity levels $\left(\mathrm{NaCl}=0,2.5,5,7.5\right.$, and $\left.10 \mathrm{~g} \cdot \mathrm{L}^{-1}\right)$. However, root dry weight (RDW) was not significantly affected by salinity. Blue grama exhibited a lower reduction in FGR and DGR than buffalograss at salinity levels lower than $10 \mathrm{~g} \cdot \mathrm{L}^{-1}$. Germination of all buffalograss cultivars and 'Hachita' blue grama was inhibited at salinity levels of 15 and $20 \mathrm{~g} \cdot \mathrm{L}^{-1} \mathrm{NaCl}$. However, buffalograss was more salt-tolerant than blue grama at the vegetative growth stage. Variations of salinity tolerance were observed within buffalograss cultivars and blue grama ecotypes, especially during the seed germination stage. Overall, buffalograss appeared to be salt-sensitive during germination but moderately salt-tolerant at the mature stage. However, blue grama was more salt-tolerant at the germination stage than the mature stage. Noticeable differences in salinity tolerance were observed between different germplasms. Therefore, salt tolerance of buffalograss and blue grama may be improved through turfgrass breeding efforts.
\end{abstract}

Buffalograss [Buchloe dactyloides (Nutt.) Englem.] and blue grama [Bouteloua gracilis (Willd. ex Kunth) Lag. ex Griffiths] are perennial, warm-season grass species native to the Great Plains. They have high tolerance to drought and heat stresses and adapted to a wide range of soil conditions (Christians, 2004). Thus, these species have high potential to be used as low-input turfgrass that can significantly reduce the demand for irrigation water, fertilizers, and pesticides (Johnson, 2007). These grasses exhibited adequate turf quality under mowed and non-mowed conditions when evaluated over a wide range of climates (Mintenko et al., 2002; Watkins et al., 2011).

High soil salinity, a common problem in turfgrass management, is caused by various

\footnotetext{
Received for publication 1 Dec. 2011. Accepted for publication 22 Feb. 2012.

This research was supported in part by Hatch Project ND01540 and NDSU Development Foundation.

We thank Drs. R. Smith and A. Zuk from the Department of Plant Sciences, North Dakota State University, for their valuable suggestions and comments when we were preparing the manuscript.

${ }^{1}$ Assistant Professor.

${ }^{2}$ Research Specialist.

${ }^{3}$ Graduate Student. Current address: Institute of Turfgrass Science, Beijing Forestry University, Beijing, China 100083.

${ }^{4}$ To whom reprint requests should be addressed; e-mail qi.zhang.1@ndsu.edu.
}

activities such as deficient precipitation, water percolation from high water tables, low-quality irrigation water, and salts from fertilizers and deicer ( $\mathrm{Wu}$ and Lin, 1993). Salinity adversely affects plant growth and development, resulting in reduced aesthetical and playable functions of turfgrass. One of the most economically effective approaches to reduce salinity problems is to use salttolerant turfgrass. Limited information is available on salinity tolerance in buffalograss and blue grama. Studies found a substantial reduction in buffalograss seed germination and seedling growth at $50 \mathrm{mM} \mathrm{NaCl}$ (Reid et al., 1993; Wu and Lin, 1993, 1994). Marcum (1999) and Marcum and Kopec (1997) assessed relative salt tolerance of eight species in the subfamily Chloridoideae, including buffalograss and grama grass (Bouteloua spp.) at the mature stage. They found that the salinity tolerance varied between species. The order of salt tolerance was as follows: saltgrass [Distichlis spicata (L.) Greene spp. stricta (Torr.) Thorne] $>$ alkali sacaton [Sporobolus airoides (Torr.) Torr.] > bermudagrass [Cynodon dactylon var. dactylon (L.). Pers] and zoysiagrass (Zoysia japonica Steud.) $>$ sand dropseed [S. cryptandrus (Torr.) A. Gray] > sideoats grama $[B$. curtipendula (Michx.) Torr.], black grama [B. eriopoda (Torr.) Torr.], and buffalograss. Mintenko and Smith (2001) estimated the salt tolerance of four native grasses, alkaligrass [Puccinellia nuttalliana (Schult.) Hitchc.], blue grama, prairie junegrass [Koeleria macrantha (Ledeb.) Schult.], and Idaho bentgrass (Agrostis idahoensis Nash), in which alkaligrass exhibited the highest tolerance [soil electrical conductivity $\left(\mathrm{EC}_{\mathrm{s}}\right) 12 \mathrm{dS} \cdot \mathrm{m}^{-1}$ or greater] than the other three species $\left(\mathrm{EC}_{\mathrm{s}}=4\right.$ to $\left.8 \mathrm{dS} \cdot \mathrm{m}^{-1}\right)$. To our knowledge, no other buffalograss and blue grama salinity trials have been published to date. The objective of this study was to determine the degree and range of salinity tolerance of five buffalograss cultivars and three blue grama ecotypes that produce adequate turf quality in field testing.

\section{Materials and Methods}

Plant material. Five buffalograss cultivars, Texoka, Cody, Bison, Sharp's Improved II, and Bowie, and three blue grama ecotypes originating from New Mexico ('Lovington' and 'Hachita') and South Dakota ('Bad River') were used for this study. These selections are widely used, commercially available, seed-type grasses, which provide the advantage of quick and low-cost establishment (Fry et al., 1997).

Seed germination. Seeds of each grass were surface-sterilized following the method of Zhang et al. (2011). Seeds were soaked with $70 \%$ ethanol for $5 \mathrm{~min}$ and then submerged in 2\% sodium hypochlorite solution for $20 \mathrm{~min}$ followed by three rinses with deionized/distilled water $\left(\mathrm{ddH}_{2} \mathrm{O}\right)$. Sterilized seeds were placed in $100 \times 15-\mathrm{mm}$ petri dishes containing $20 \mathrm{~mL}$ of $0.6 \%$ agar (SigmaAldrich Co., St. Louis, MO) supplemented with $0,5,10,15$, or $20 \mathrm{~g} \cdot \mathrm{L}^{-1} \mathrm{NaCl}$. The EC of the salt solutions was $0.0,8.4,15.1,21.0$, and $26.1 \mathrm{dS} \cdot \mathrm{m}^{-1}$, respectively, measured with an EC meter (Model 1054; VWR International LLC, West Chester, PA). The medium was autoclaved at $121{ }^{\circ} \mathrm{C}$ and $103 \mathrm{kPa}$ for $20 \mathrm{~min}$ before pouring into petri dishes. Thirty seeds were placed in each petri dish. Dishes were arranged in a randomized complete block design in three separate incubators (Model I-35 VL; Percival Scientific, Perry, IA) at $30 / 25{ }^{\circ} \mathrm{C}$ (day/night) under fluorescent light $\left(36 \mu \mathrm{mol} \cdot \mathrm{s}^{-1} \cdot \mathrm{m}^{-2}\right)$ with a 12 - to 12-h photoperiod (Association of Official Seed Analysts, 2004). The number of germinated seeds per dish was counted three times a week for 4 weeks. The petri dishes were rotated after each counting to minimize the shelf effect. A seed was considered to be germinated when its emerged shoot was visible under $2 \times$ magnification (McCarty and Dudeck, 1993). Final germination rate and DGR were calculated following the method of Zhang et al. (2011) in which FGR (\%) = $100 \times\left[\left(\sum n\right) / 30\right]$ and DGR $(\% / \mathrm{d})=100 \times$ $\left[\sum(n / D)\right] / 30$, respectively, where $n$ was the number of new seeds germinated at each counting and $D$ was the number of days accumulated up to that counting. To provide an accurate indication of salinity tolerance, FGR and DGR under saline conditions were standardized as the percentage of control $\left(0 \mathrm{~g} \cdot \mathrm{L}^{-1} \mathrm{NaCl}\right)$ (Teolis et al., 2009) and the higher the ratio of the saline level to control, the greater the salinity tolerance. 
This experiment consisted of three replicates (incubators) with an eight (grasses) $\times$ five (salinity levels) factorial arrangement. All data were subjected to PROC GLM (SAS, 2004). Means were separated with Fisher's protected least significant difference at $P \leq$ 0.05 .

Vegetative growth. Buffalograss and blue grama were sown into $46 \times 61-\mathrm{cm}$ flats containing Sunshine LC1 Mix (Sun Gro Horticulture Distribution Inc., Bellevue, WA) in Apr. 2011 in a greenhouse on the North Dakota State University campus. Grasses were mowed at $7.5 \mathrm{~cm}$ once a week and handwatered every other day after germination. A water-soluble fertilizer $(20.0 \mathrm{~N}-8.4 \mathrm{P}-$ 16.6K; JR Peters, Inc., Allentown, PA) was applied at $12.5 \mathrm{~kg} \cdot \mathrm{ha}^{-1}$ nitrogen once a month. Grasses were exposed to saline conditions after a 5-month establishment period in the greenhouse.

Salinity tolerance of mature grasses was determined using a hydroponic system following the method of Dai et al. (2009). Each grass was represented by six tillers randomly selected from the flats. Tillers were transplanted to foam plates $(30 \times 25 \times 2 \mathrm{~cm})$ with eight cells $(6.0 \mathrm{~cm}$ in diameter $)$ per plate filled with Sunshine LC1 Mix. Nylon screen was glued to the bottom of the foam plate to support the growing media but allow roots to penetrate through. The hydroponic system was comprised of 15 containers (five salinity levels $\times$ three replicates), which were constantly aerated with half-strength Hoagland's solution (Hoagland and Arnon, 1939) and various $\mathrm{NaCl}$ solutions. In a preliminary experiment, substantial growth reduction and complete death were observed at $10 \mathrm{~g} \cdot \mathrm{L}^{-1}$ $\mathrm{NaCl}$ and higher saline conditions (15 and $20 \mathrm{~g} \cdot \mathrm{L}^{-1} \mathrm{NaCl}$ ), respectively, 1 week after saline exposure. Therefore, salinity levels were set at 0 (control), 2.5, 5.0, 7.5, and $10.0 \mathrm{~g} \cdot \mathrm{L}^{-1}$ $\mathrm{NaCl}$ (final $\mathrm{EC}=1.1,5.6,9.1,12.5,16.3$ $\left.\mathrm{dS} \cdot \mathrm{m}^{-1}\right)$. The solution was refreshed once a week. Sodium chloride was added gradually over a 4-d period to reach the final concentration. At Day 4, grasses were mowed at $7.5 \mathrm{~cm}$ and all roots were clipped at the base of the foam plate to assure a uniform start.

Tillers were hand-mowed once a week at $7.5 \mathrm{~cm}$ and clippings were collected for a period of 3 weeks. Clippings were ovendried at $65{ }^{\circ} \mathrm{C}$ for $48 \mathrm{~h}$ and weighed. All clippings were combined to determine SDW for each grass. At the end of Week 3, roots were harvested. Data were collected on the LRL and RDW (oven-dried for $48 \mathrm{~h}$ at $65^{\circ} \mathrm{C}$ ). Percentage of green tissue was rated visually on a $0 \%$ to $100 \%$ scale when the experiment was ended (Week 3).

The experiment was conducted twice from 3 to 27 Sept. (Expt. I) and 8 Oct. to 1 Nov. (Expt. II) in 2011. Both experiments were arranged in a split-plot design with salinity levels being the whole plot factor and grasses being the subplot factor. Data under saline conditions were expressed as percentage of control $\left(\mathrm{NaCl}=0 \mathrm{~g} \cdot \mathrm{L}^{-1}\right)$ to accurately represent salt tolerance as aforementioned when analyzing seed germination.
Data were subjected to PROC GLM (SAS, 2004) and means were separated with Fisher's protected least significant difference at $P \leq$ 0.05 .

\section{Results}

Seed germination. A significant grass $x$ salinity interaction was observed in FGR under the saline conditions (Fig. 1). At $5 \mathrm{~g} \cdot \mathrm{L}^{-1}$ $\mathrm{NaCl}$, the blue grama ecotypes, 'Lovington' and 'Bad River', had the highest FGR (averaging $94.7 \%$ of control) followed by 'Texoka' buffalograss (66.0\% of control) and 'Hachita' blue grama ( $52.6 \%$ of control) and all other grasses had FGR lower than $50 \%$ of control (averaging $27.5 \%$ of control) (Fig. 1). As salinity level increased to $10 \mathrm{~g} \cdot \mathrm{L}^{-1} \mathrm{NaCl}$, FGR of 'Lovington' and 'Bad River' blue grama was significantly higher than the other grasses. When the salinity level was increased to $15 \mathrm{~g} \cdot \mathrm{L}^{-1} \mathrm{NaCl}$, 'Lovington' and 'Bad River' germination averaged $8.5 \%$ of control in FGR. Except for 'Bad River' blue grama, other grasses did not germinate when the salinity level reached $20 \mathrm{~g} \cdot \mathrm{L}^{-1} \mathrm{NaCl}$.

A grass $\times$ salinity interaction was also observed in DGR under saline conditions (Fig. 2). When data were pooled across grasses, the average DGR was $48.05 \%$, $12.9 \%, 3.8 \%$, and $0.4 \%$ of control at salinity levels of $5,10,15$, and $20 \mathrm{~g} \cdot \mathrm{L}^{-1} \mathrm{NaCl}$, respectively. Of eight grasses, 'Bad River' and 'Lovington' blue grama and 'Texoka' buffalograss showed $50 \%$ or more DGR at $5 \mathrm{~g} \cdot \mathrm{L}^{-1} \mathrm{NaCl}$ compared with the control treatment. The DGR of 'Bad River' and 'Lovington' blue grama was significantly higher than that of the other grasses at salinity levels of 10 to $15 \mathrm{~g} \cdot \mathrm{L}^{-1} \mathrm{NaCl}$. 'Bad River' blue grama was the only grass to germinate at $20 \mathrm{~g} \cdot \mathrm{L}^{-1} \mathrm{NaCl}$ with a DGR of $0.4 \%$ of the control treatment.

Vegetative growth. Because Expts. I and II were homogeneous, data were pooled across both trials (data not shown). No interaction between grass and salinity was observed in vegetative growth under saline conditions (data not shown). With the exception of RDW, plant growth decreased as salinity levels increased (Table 1); however, variations in growth were observed when different parameters were calculated. For example, LRL and PGT were reduced $37.3 \%$ and $40.3 \%$, respectively, when $\mathrm{NaCl}$ was increased from 0 to $2.5 \mathrm{~g} \cdot \mathrm{L}^{-1}$. All grasses showed less than 50\% LRL and PGT of control when the saline level was $5.0 \mathrm{~g} \mathrm{~L}^{-1}$ or greater; however, reductions in SDW exceeded $50 \%$ only when salinity level was increased to $10 \mathrm{~g} \cdot \mathrm{L}^{-1} \mathrm{NaCl}$.

All grasses exhibited similar RDW when data were pooled across all salinity levels (Table 2). Variations in SDW were observed across all grasses. 'Bowie' buffalograss only showed a $1.5 \%$ reduction (from $100 \%$ to $98.5 \%$ ) in SDW after 3 weeks of saline exposure, whereas 'Bison' buffalograss and 'Lovington' blue grama showed an average reduction of $16.8 \%$. 'Texoka' and 'Cody' buffalograss and 'Hachita' blue grama showed an average reduction of $39.3 \%$. 'Sharp's Improved II' buffalograss and 'Bad River' blue grama had the highest reduction $(54.1 \%)$ in SDW. Reduction in LRL and PGT was higher than SDW. For example, all grasses showed more than $50 \%$ reduction in LRL after a 3-week salt treatment, in which 'Lovington' and 'Hachita' blue grama exhibited the highest reduction $(83.8 \%)$. Similarly, PGT was reduced more than $50 \%$ in all grasses except 'Texoka' buffalograss after 3 weeks of growth in saline solutions.

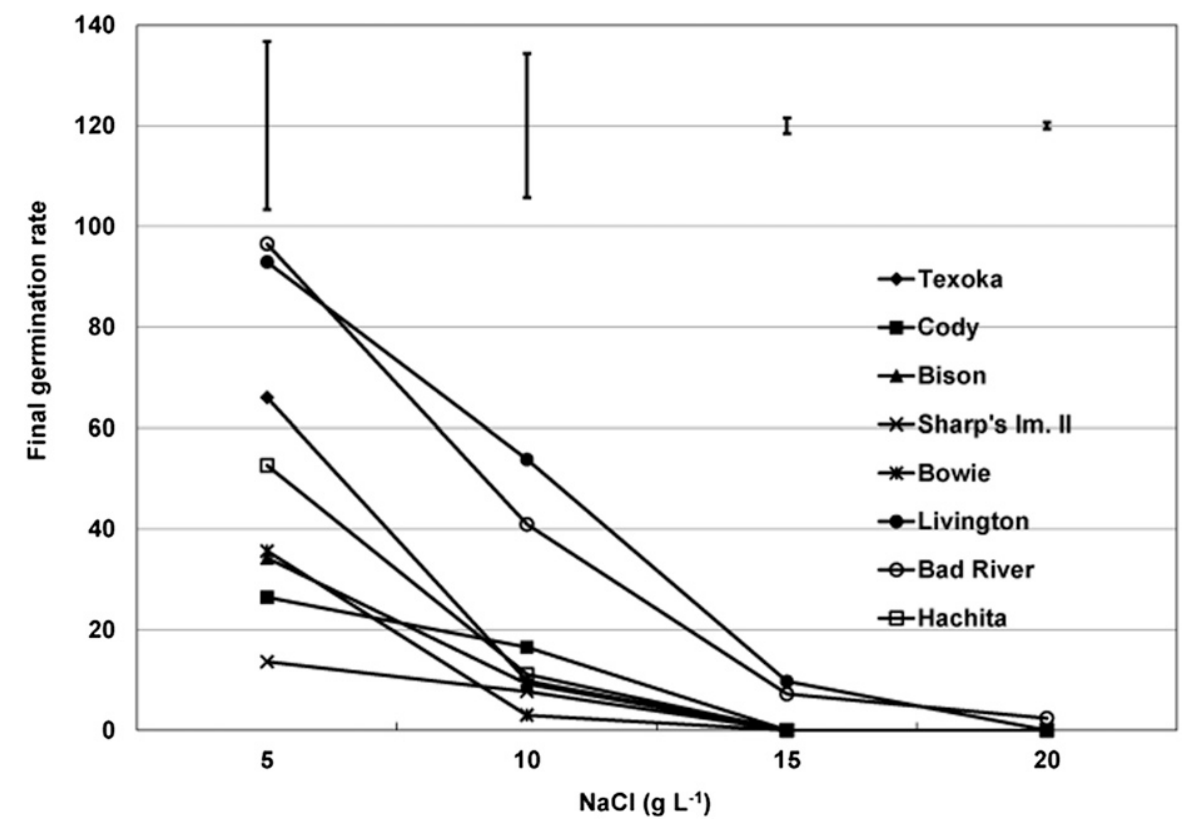

Fig. 1. Final germination rate of buffalograss ('Texoka', 'Cody', 'Bison', 'Sharp's Improved II', and 'Bowie') and blue grama ('Lovington', 'Bad River', and 'Hachita') as affected by salinity ( $\left.\mathrm{g} \cdot \mathrm{L}^{-1} \mathrm{NaCl}\right)$. Data were presented as percent of control $\left(0 \mathrm{~g} \cdot \mathrm{L}^{-1} \mathrm{NaCl}\right)$. Vertical bars represented the least significant means (LSD) at $P \leq 0.05$. 


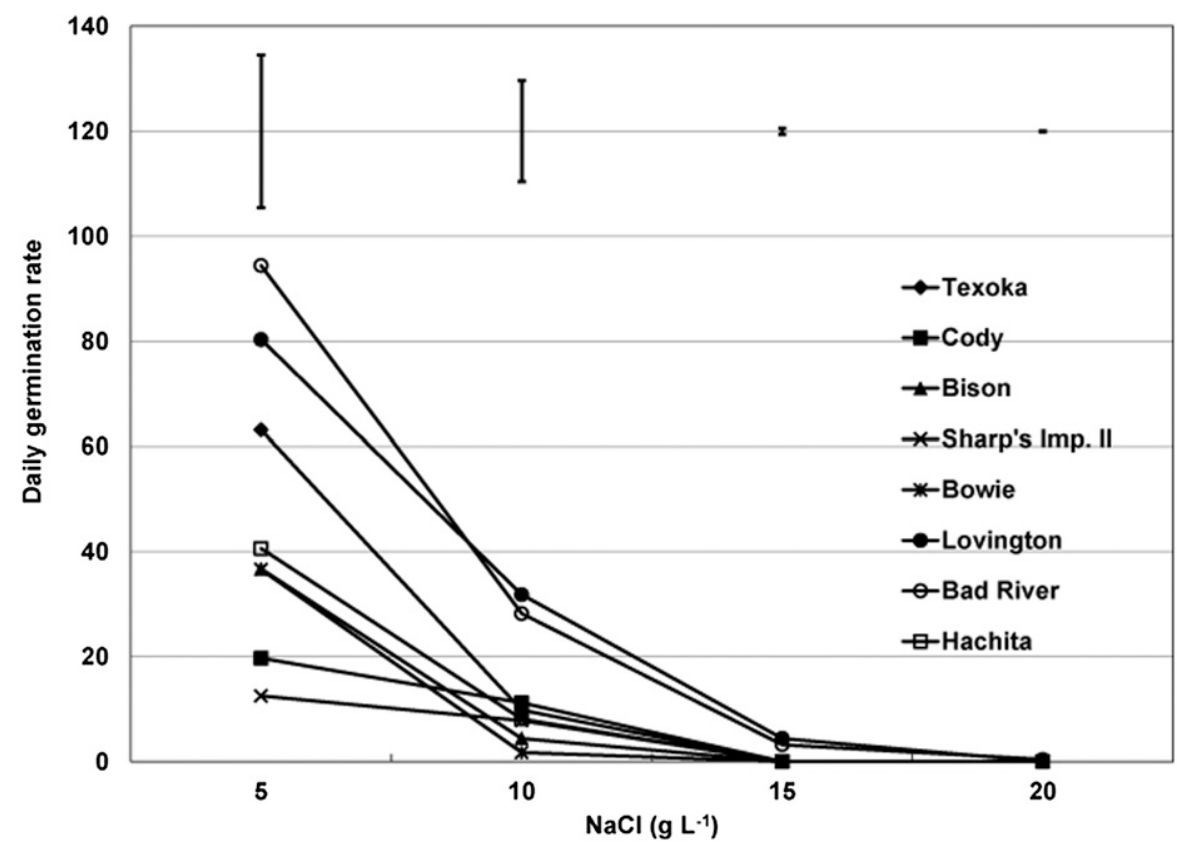

Fig. 2. Daily germination rate of buffalograss ('Texoka', 'Cody', 'Bison', 'Sharp's Improved II', and 'Bowie') and blue grama ('Lovington', 'Bad River', and 'Hachita') as affected by salinity ( $\left.\mathrm{g} \cdot \mathrm{L}^{-1} \mathrm{NaCl}\right)$ Data were presented as percent of control $\left(0 \mathrm{~g} \cdot \mathrm{L}^{-1} \mathrm{NaCl}\right)$. Vertical bars represented the least significant means (LSD) at $P \leq 0.05$.

Table 1. The effect of salinity on shoot dry weight (SDW), root dry weight (RDW), longest root length (LRL), and percentage of green tissue (PGT) of buffalograss and blue grama.

\begin{tabular}{ccccc}
\hline $\mathrm{NaCl}\left(\mathrm{g} \cdot \mathrm{L}^{-1}\right)$ & $\mathrm{SDW}^{\mathrm{z}}$ & $\mathrm{RDW}^{\mathrm{z}}$ & $\mathrm{LRL}^{\mathrm{z}}$ & $\mathrm{PGT}^{\mathrm{z}}$ \\
\hline 2.5 & $103.3 \mathrm{a}^{\mathrm{y}}$ & $73.3 \mathrm{a}$ & $62.7 \mathrm{a}$ & $59.7 \mathrm{a}$ \\
5.0 & $68.8 \mathrm{~b}$ & $64.4 \mathrm{a}$ & $36.2 \mathrm{~b}$ & $41.8 \mathrm{~b}$ \\
7.5 & $55.6 \mathrm{bc}$ & $34.6 \mathrm{a}$ & $19.9 \mathrm{c}$ & $20.9 \mathrm{c}$ \\
10.0 & $41.9 \mathrm{c}$ & $33.6 \mathrm{a}$ & $18.7 \mathrm{c}$ & $16.6 \mathrm{c}$ \\
\hline
\end{tabular}

${ }^{2}$ Data were represented as percent of control $\left(0 \mathrm{~g} \cdot \mathrm{L}^{-1} \mathrm{NaCl}\right)$.

${ }^{y}$ Means followed by the same letters in each column are not significantly different at $P \leq 0.05$.

Table 2. Shoot dry weight (SDW), root dry weight (RDW), longest root length (LRL), and percentage of green tissue (PGT) of buffalograss and blue grama after 3 weeks growth in saline solutions $(\mathrm{NaCl}=2.5$, $5,7.5$, and $\left.10 \mathrm{~g} \cdot \mathrm{L}^{-1}\right)$.

\begin{tabular}{lllll}
\hline Grass & SDW $^{\mathrm{z}}$ & RDW $^{\mathrm{z}}$ & LRL $^{\mathrm{z}}$ & PGT $^{\mathrm{z}}$ \\
\hline Buffalograss & & & & \\
$\quad$ Texoka & $61.9 \mathrm{bc}^{\mathrm{y}}$ & $30.2 \mathrm{a}$ & $47.2 \mathrm{a}$ & $56.9 \mathrm{a}$ \\
Cody & $64.0 \mathrm{bc}$ & $57.9 \mathrm{a}$ & $41.6 \mathrm{a}$ & $49.6 \mathrm{bc}$ \\
Bison & $86.9 \mathrm{ab}$ & $68.2 \mathrm{a}$ & $49.5 \mathrm{a}$ & $39.0 \mathrm{c}$ \\
Sharp's improved II & $49.5 \mathrm{c}$ & $86.2 \mathrm{a}$ & $33.8 \mathrm{ab}$ & $36.6 \mathrm{~cd}$ \\
Bowie & $98.5 \mathrm{a}$ & $77.0 \mathrm{a}$ & $31.2 \mathrm{ab}$ & $36.5 \mathrm{~cd}$ \\
Blue grama & & & & \\
$\quad$ Lovington & $79.5 \mathrm{ab}$ & $17.2 \mathrm{a}$ & $19.3 \mathrm{~b}$ & $14.6 \mathrm{e}$ \\
Bad River & $42.4 \mathrm{c}$ & $59.6 \mathrm{a}$ & $35.2 \mathrm{ab}$ & $22.5 \mathrm{de}$ \\
Hachita & $56.3 \mathrm{bc}$ & $15.3 \mathrm{a}$ & $17.1 \mathrm{~b}$ & $22.2 \mathrm{de}$ \\
\hline
\end{tabular}

${ }^{2}$ Data were represented as percent of control $\left(0 \mathrm{~g} \cdot \mathrm{L}^{-1} \mathrm{NaCl}\right)$.

${ }^{\mathrm{y}}$ Means followed by the same letters in each column are not significantly different at $P \leq 0.05$.

\section{Discussion}

Uniform germination is essential for successful turfgrass establishment. High DGR and FGR indicate a high potential for successful establishment. The result of this study showed that salinity reduced DGR and FGR in buffalograss and blue grama (Figs. 1 and 2). However, the reduction of DGR was higher than FDR, indicating that DGR is more sensitive to salinity stress than FGR, which levels. Limited variations in salt tolerance were observed in the other grasses under saline conditions, except $5 \mathrm{~g} \cdot \mathrm{L}^{-1}$.

Salinity adversely affects plant growth and functionality; however, its impact varies in different parameters. Almansouri et al. (1999) reported higher reduction in shoot growth in 'Cando' durum wheat (Triticum durum Desf.) (salt-sensitive) than in 'Belikh' (salt-tolerant); however, both cultivars showed a similar level of root growth. Mintenko and Smith (2001) suggested that turfgrass quality was more important than other characteristics, including growth as a result of the aesthetical function of turfgrass. In this study, RDW was unaffected by salinity (Table 1), which might be the result of the large variations within the samples. Shoot dry weight, LRL, and PGT decreased as salinity levels were increased. The results of this study also showed that the reduction of LRL and PGT was more severe than losses in SDW as salinity levels were increased, indicating that LRL and PGT were more sensitive to salinity stress and they might be better indices for screening salinity-tolerant grasses.

Salinity tolerance of buffalograss and blue grama at the germination and vegetative growth stages was compared. In buffalograss, the decrease in DGR and FGR was greater than that of blue grama. Seed germination was completely inhibited in buffalograss when the salinity level reached $15 \mathrm{~g} \cdot \mathrm{L}^{-1}$ $\mathrm{NaCl}$, whereas blue grama grasses still averaged $5.6 \%$ and $0.8 \%$ FGR at salinity levels of 15 and $20 \mathrm{~g} \cdot \mathrm{L}^{-1} \mathrm{NaCl}$, respectively (Figs. 1 and 2). The results indicated that blue grama was more salt-tolerant than buffalograss during germination. However, an opposite trend was observed at the vegetative growth stage. Blue grama showed a higher reduction in vegetative growth than buffalograss under the saline conditions, particularly in LRL and PGT. The average LRL and PGT of buffalograss were $40.7 \%$ and $43.7 \%$, respectively, whereas they were only $23.9 \%$ and $19.7 \%$ in blue gramaes, respectively (Table 2). Variations in salt tolerance during seed germination and vegetative growth have been reported in other plants such as ryegrass (Lolium spp.), annual bluegrass (Poa annua L.), and prairie junegrass (Dai et al., 2009; Marcar, 1987; Wang and Zhang, 2011). It is speculated that mechanisms of salinity tolerance differ in growth stages (Rose-Fricker and Wipff, 2001).

Differences in salt tolerance were observed within species. In the five buffalograss cultivars tested in this study, 'Texoka' showed $66.0 \%$ and $63.1 \%$ of FGR and DGR, respectively, at $5 \mathrm{~g} \cdot \mathrm{L}^{-1} \mathrm{NaCl}$ compared with $27.4 \%$ and $26.5 \%$ of the other buffalograss cultivars (Figs. 1 and 2). As salinity levels increased to $10 \mathrm{~g} \cdot \mathrm{L}^{-1}$ or higher, buffalograss cultivars exhibited similar FGR and DGR. At the vegetative growth stage, 'Texoka' had the highest PGT under the saline exposure (Table 2). Within blue grama treatments, 'Lovington' and 'Bad River' exhibited a higher FGR and DGR than 'Hachita'; however, blue grama ecotypes exhibited similar performance during the vegetative growth stage (Table 2). 
Such variations in salt tolerance within buffalograsses were also reported by Reiten et al. (1992) and Wu and Lin (1993); however, they reported limited variations in salinity tolerance in buffalograss at maturity. Such differences in salinity tolerance in grasses observed in this study and previous research may be as result of different cultivars used in the experiments or various quantified parameters used in each study (Almansouri et al., 1999).

Our results demonstrated that salt tolerance of buffalograss increased after seed germination. However, salt tolerance of blue grama decreased as seedling reached the mature stage. Variations in salinity tolerance within buffalograss and blue grama germplasms illustrate the potential to improve salt tolerance of turfgrass species through breeding.

\section{Literature Cited}

Almansouri, M., J.M. Kinet, and S. Lutts. 1999. Compared effects of sudden and progressive impositions of salt stress in three durum wheat (Triticum durum Desf.) cultivars. J. Plant Physiol. 154:743-752.

Association of Official Seed Analysts. 2004. Rules for testing seeds. Association of Official Seed Analysts, Ithaca, NY.

Christians, N. 2004. Fundamentals of turfgrass management. 2nd Ed. John Wiley and Sons, Inc., Hoboken, NJ.

Dai, J., D.R. Huff, and M.J. Schlossberg. 2009. Salinity effects on seed germination and vegetative growth of green-type Pоа аппиа relative to other cool-season turfgrass species. Crop Sci. 49:696703.

Fry, J.D., R.E. Gaussoin, D.D. Beran, and R.A. Masters. 1997. Buffalograss establishment with preemergence herbicides. HortScience 32:683686.

Hoagland, D.R. and D.I. Arnon. 1939. The waterculture method for growing plants without soil. Agr. Exp. Stn. Circ. 347. Univ. of Calif., Berkeley, CA.

Johnson, P.G. 2007. Native grasses as droughttolerant turfgrasses of the future, p. 619-640. In: Pessarakli, M. (ed.). Handbook of turfgrass management and physiology. CRC Press, Boca Raton, FL.

Marcar, N.E. 1987. Salt tolerance in the genus Lolium (ryegrass) during germination and growth. Aust. J. Agr. Res. 38:297-307.

Marcum, K.B. 1999. Salinity tolerance mechanisms of grasses in the subfamily Chloridoideae. Crop Sci. 39:1153-1160.

Marcum, K.B. and D.M. Kopec. 1997. Salinity tolerance of turfgrasses and alternative species in the subfamily Chloridoideae (Poaceae). Intl. Turfgrass Sco. Res. J. 8:735-742.

McCarty, L.B. and A.E. Dudeck. 1993. Salinity effects on bentgrass germination. HortScience 28:15-17.

Mintenko, A. and R. Smith. 2001. Native grasses vary in salinity tolerance. Golf Course Mgt. 69:55-59.

Mintenko, A.S., S.R. Smith, and D.J. Cattani. 2002. Turfgrass evaluation of native grasses for the northern Great Plains region. Crop Sci. 42:2018 2024.
Reid, S.D., A.J. Koski, and H.G. Hughes. 1993. Buffalograss seedling screening in vitro for $\mathrm{NaCl}$ tolerance. HortScience 28:536.

Reiten, J.G., C.W. Lee, Z.M. Cheng, and R.C. Smith 1992. Germination salt tolerance of kentucky bluegrass (Poa pratensis) and buffalograss (Buchloe datyloides) seeds. HortScience 27:676.

Rose-Fricker, C. and J.K. Wipff. 2001. Breeding for salt tolerance in cool-season turf grasses. Intl. Turfgrass Soc. Res. J. 9:206-212.

SAS. 2004. SAS 9.1.2 qualification tools user's guide. SAS Institute Inc., Cary, NC.

Teolis, I., W. Liu, and E.B. Peffley. 2009. Salinity effects on seed germination and plant growth of guar. Crop Sci. 49:637-642.

Wang, S. and Q. Zhang. 2011. Evaluation of salinity tolerance of prairie junegrass, a potential low-maintenance turfgrass species. HortScience 46:1038-1043.

Watkins, E., S. Fei, D. Gardner, J. Stier, S. Bughrara, D. Li, C. Bigelow, L. Schleicher, B. Horgan, and K. Diesburg. 2011. Low-input turfgrass species for the north central United States. Online. Applied Turfgrass Science. doi: 10.1094/ATS2011-0126-02-RS.

Wu, L. and H. Lin. 1993. Salt concentration effects on buffalograss germplasm seed germination and seedling establishment. Intl. Turfgrass Soc. Res. J. 7:823-828.

$\mathrm{Wu}, \mathrm{L}$. and H. Lin. 1994. Salt tolerance and salt uptake on diploid and polyploidy buffalograss (Buchloë dactyloides). J. Plant Nutr. 17:19051928.

Zhang, Q., S. Wang, and K. Rue. 2011. Salinity tolerance of 12 turfgrasses in three germination media. HortScience 46:651-654. 